\author{
Dr. sc. Andrea Lučić * \\ Tamara Jakopanec, mag. oec. ${ }^{* *}$
}

\title{
ISTRAŽIVANJE POVEZANOSTI ETIKE VRLINA I ZADOVOLJSTVA ORGANIZACIJOM
}

\section{EXPLORING THE RELATIONSHIP OF VIRTUE ETHICS AND ORGANIZATIONAL SATISFACTION}

\begin{abstract}
SAŽETAK: U ovome radu će se razmatrati etika vrlina, etički koncept koji temelji etiku na karakternim osobinama, a ne na pravilima i ima široku primjenu u poslovnom svijetu. Takav pogled sugerira analizu etičkih kvaliteta organizacije gdje se određena aktivnost smatra vrlinom samo onda kada iza nje stoje ispravni motivi. Okosnicu karaktera etičkog poduzeća predstavljaju optimizam, povjerenje, integritet, empatija i oprost. Cilj ovoga rada je istražiti primjenu odabranog koncepta te istaknuti dostignuća s područja etike vrlina koja su se upotrijebila u praksi. Ovaj rad po prvi puta empirijski spaja pojmove etike vrlina te zadovoljstva organizacijom kombiniranom metodom istraživanja. Provedeno je izviđajno kvalitativno istraživanje s ciljem ispitivanja stavova visokopozicioniranih stručnjaka o kompatibilnosti osobnih i profesionalnih vrlina te zadovoljstva organizacijom koje iz toga proizlazi s ciljem istraživanja opravdanosti povezivanja tih pojmova. Kvantitativno istraživanje na uzorku od 168 stručnjaka dalo je detaljan uvid potvrđene hipoteze utjecaja etike vrlina i zadovoljstva organizacijom. Istraživanje je pokazalo kako je povjerenje ono koje ima najveći utjecaj na zadovoljstvo organizacijom.
\end{abstract}

KLJUČNE RIJEČI: etika vrlina, moralni karakter, zadovoljstvo organizacijom, Hrvatska.

\begin{abstract}
The paper is set around the virtue ethics, widely applicable ethical concept that is based on the ethical character traits and not on the written rules. Such approach suggests the analysis of the organizational ethical quality that is considered virtuous only when backed up by the correct motives. Pillars of virtue ethics and ethical character are optimism, trust, integrity, empathy and forgiveness. The aim of this paper is to investigate the implementation of the concept and to highlight the practical implications. The paper's
\end{abstract}

\footnotetext{
Dr. sc. Andrea Lučić, andrea.lucic@efzg.hr, Ekonomski fakultet Zagreb.
} Tamara Jakopanec, mag. oec., jakopanectamara@gmail.com, Podravka. 
novelty arises from the investigation of virtue ethics with roganizational satisfaction investigated with a mixed method approach. We conducted exploratory qualitative research on the sample of highly-ranked employees in order to investigate the compatibility of personal and profesionaal virtues and organizational satisfaction with the aim to confirm such conection. Quantitative research was conducted on the sample of 168 experts and gave a detailed insight into the virtue ethics of Croatian organization, and showed that trust has the greatest impact on an organizational satisfaction.

KEY WORDS: Virtue Ethics, Moral character, Organization satisfaction, Croatia.

\section{UVOD}

Posljednjih godina došlo je do povećanog zanimanja za provedbu Aristotelijanske etike vrlina u poslovnu etiku. Sve se veći naglasak i briga stavlja na moralnost menadžmenta, a kreće se prema pronalasku prirodnog etičkog sustava koji će eliminirati neželjene posljedice od neetičnih menadžerskih aktivnosti (Moore, 2008.; Anca, 2010.). U ovome radu će se razmatrati tema etike vrlina, etički koncept koji temelji etiku na karakternim osobinama, a ne na pravilima i ima široku primjenu u poslovnom svijetu (Bertland, 2009.).

Najzanimljivija perspektiva etike jest etika vrlina koja promatra karakter vrlina korporacije i implikacija koje one imaju za etiku organizacije (Murphy, 1999.). Takav pogled sugerira analizu etičkih kvaliteta poduzeća i njegovih članova te se iz perspektive etike vrlina određena aktivnost smatra vrlinom samo onda kada iza nje stoje ispravni motivi. Vrline etičke organizacije su poštenje, pravednost, reputacija, predanost, transparentnost, integritet i povjerenje (Murphy et al., 2007.).

$\mathrm{S}$ obzirom da je u središtu koncepta etike vrlina pojedinac, na poduzeća se gleda kroz prizmu pojedinca i njegovog utjecaja na poduzeće kao i doprinosa etičnom poslovanju poduzeća. Cilj ovoga rada je istražiti primjenu odabranog koncepta te istaknuti dostignuća s područja etike vrlina koja su se upotrijebila u praksi. Ovaj rad po prvi puta empirijski spaja pojmove etike vrlina te zadovoljstva organizacijom kombiniranom metodom istraživanja. Vodeći se preporukom Camerona i drugih (Cameron 2003., Cameron et al., 2004.) nedovoljne istraženosti organizacijske manifestacije etike vrlina provedeno je kvalitativno i kvantitativno istraživanje. Izviđajno kvalitativno istraživanje imalo je cilj ispitivanje stavova visokopozicioniranih stručnjaka o kompatibilnosti osobnih i profesionalnih vrlina te zadovoljstva organizacijom koje iz toga proizlazi s ciljem istraživanja opravdanosti povezivanja tih pojmova. U sklopu izviđajnog istraživanja provedeno je deset dubinskih intervjua u različitim hrvatskim poduzećima. Ne bi li se dobio detaljan uvid u etičke vrline hrvatskih poduzeća te da se istraži povezanost pojedinih organizacijskih vrlina i zadovoljstva organizacijom provedeno je kvantitativno istraživanje na uzorku stručnjaka od 168 ispitanika.

\section{ORGANIZACIJSKA PRIMJENA ETIKE VRLINA}

Poduzeća, pred imperativom kontinuiteta postojanja na tržištu, uz stvaranje komparativnih prednosti moraju razborito koristiti sredstva koja ulažu u osnovno poslovanje, ali i u društvenu odgovornost. Iz posljedične perspektive procesa, ako su ulaganja korištena 
na način da unaprjeđuju rezultate društveno odgovornog poslovanja to djeluje i na konkurentske prednosti te na cjelokupne doprinose poduzeća društvu. Ako se takva, čisto profitno-orijentirana strategija, komunicira prema potrošačima dovodi do preisipitivanja stavova potrošača o aktivnostima poduzeća. Upravo tu dolazi do kolizije s etikom vrlina zbog artikulacije stvarne motivacije koja stoji iza strategije društveno odgovornog poslovanja. Ako se interesi poduzeća svode na ograničenu profitnu orijentaciju to u biti smanjuje moralnu vrijednost takvih aktivnosti. Ako, s druge strane, poduzeće pristupa društveno odgovornom poslovanju u vjeri da će se na taj način proizvesti najviše «dobroga» za sve uključene strane, to se može smatrati čestitim ponašanjem i poslovanjem.

\subsection{Definiranje područja etike vrlina}

„Etika vrlina ili aretička etika jest teorija ili, radije, struja u suvremenoj etici prema kojoj prioritet u vrednovanju imaju karakterne osobine ljudi, a ne njihovi postupci, kao što to misle zastupnici deontološke etike, ili pak posljedice njihovih postupaka, kao što to misle zastupnici konzekvencijalističke etike" (Berčić, 2008.). U etici vrlina, aktivnosti se klasificiraju dobrima ako proizlaze iz karaktera osobe koja je čestita - one su potreban element koji omogućuje napredak i dobro življenje (Bruni i Sugden, 2013.). MacIntyre (1984.) definira etiku vrlina kao 'običaj koji nam nalaže ne samo da se ponašamo na određeni način, već i da osjećamo na određeni način.’ Također, MacIntyre (1984.) ističe da je čestita aktivnost drugačija od uvježbanih moralnih i kvalitetnih aktivnosti agenata koji te moralne radnje uvježbavaju i provode zato što su primjerene određenim situacijama (Mintz, 1996.). Prema MacIntyeru (2007.), vrline ne pomažu samo u ostvarivanju dobre prakse, već pomažu praksi da se zaštiti od korupcije koja je rezultat agentske potjere za vanjskim, dodatnim dobrima (Garcia-Ruiz i Rodriguez-Lluesama, 2014.). Organizacije vrlina imaju pet obilježja (Cameron, 2003.):

- Vrline potiču smisao, blagostanje i oplemenjuju ljude

- Iskustvo vrlina je kognitivno, emocionalno i bihevioralno

- Vrline potiču sklad u odnosima

- Vrline se samo obnavljaju

- Vrline služe kao ublaživač i potiču otpornost organizacije.

Čestiti institucionalni ili organizacijski karakter može se definirati kao skup vrlina koje su potrebne da bi organizacija sudjelovala u aktivnostima s određenom izvrsnošću, fokusirajući se na dostižna interna dobra istovremeno se braneći od korupcijske snage drugih institucija iz iste okoline (Moore, 2008.). Aranzadi (2013.) ističe povezanost poduzeća, zaposlenika i poduzetničke klime koja vlada u tom poduzeću. Prema njemu, ta tri sustava međusobno su povezana i dio su većeg zajedničkog sustava. Ideju o tome da poduzeće može imati vrline i biti čestito predstavlja Collier (1995.). Takvo poduzeće ima četiri glavna obilježja: osjetljivost prema svrsi postojanja, pronicljivost glede ljudskog uspjeha, posjedovanje znanja za pravodobnu i konkretnu aktivnost zbog ispunjenja svrhe postojanja i kvalitete potrebne za postizanje i održavanje dobre menadžerske prakse (Murphy, 1999.). Ako je poduzeće moralno i vodi se etikom vrlina, ono je okrenuto ostvarivanju zajedničkih koristi s okolinom i članovima te okoline, međutim, postavlja se pitanje na koji način se poduzeće okreće u tome smjeru i kako do toga doći (Koehn, 1998.). Ključna stavka u tome procesu 
jesu menadžeri - dobar menadžment nastoji njegovati okolinu u kojoj ljudi žele raditi jedni s drugima (Koehn, 1998.). Kako bismo došli u fazu posjedovanja vrlina u cijelosti, moramo shvatiti da vrline ne možemo koristiti i iskazivati povremeno i po potrebi, čestite aktivnosti slijede iz čvrstog i dosljednog karaktera (McPherson, 2013.).

\subsection{Dimenzije etičkih vrlina organizacije}

S obzirom na različite perspektive mnogo je načina na koje se može promatrati vrline organizacije kao što su oprost, integritet, poštenje, poniznost, nada, briga, suosjećanje, hrabrost, iskrenost, ljubav, predanost itd. Peterson i Seligman (2003.) su razradili set od 25 dimenzija etičkih vrlina organizacije koje se u svojoj primjeni nekad i preklapaju (Cameron et al., 2004.). Cameron i drugi (2004.) su vrline promatrali kroz 5 faktora u procesu formiranja mjerila za etiku vrlina, a promatrali su - organizacijski oprost, povjerenje, integritet, optimizam i empatiju.

Optimizam predstavlja pozitivan stav i pogled na situaciju bez obzira na to koliko je izvjesno da se to uistinu i dogodi. Optimizam predstavlja konstruktivno stanje koje uvijek treba održavati, jer stvara okolinu i kulturu promicanja da se uvijek sve može riješiti i da dobrohotno poslovanje uvijek ima smisla (Annas, 2015.).

Prema Rotteru (1967.) „Povjerenje je generalizirano očekivanje jedne strane da je pouzdano osloniti se na riječ druge strane“ (Murphy et al., 2007.). Ako se povjerenje stječe na realnoj osnovi i povjerenju u bilo kojemu poslovnom kontekstu, može donijeti samo probitak za sve strane u poslovnoj suradnji (Dobson, 2007.).

Empatija je vrlina koja ima vrlo jednostavno značenje - biti u mogućnosti staviti sebe na mjesto drugih (Murphy, 1999.). Postojanje empatije unutar organizacije, ne pretpostavlja dijeljenje milostinje, već davanje prilike, pretpostavlja suradnju i brigu za drugoga (Annas, 2015.). Empatija, čini se, ima kritičnu važnost za dugoročni uspjeh u organizaciji, jer i zaposlenici i potrošači reagiraju na tu vrlinu, stoga će menadžeri koji ju posjeduju biti znatno uspješniji u svome radu (Murphy, 1999.). Laži, prijevare i poluistine možda će osigurati kratkoročne probitke, no na duži rok se samo istinitost isplati (Hursthouse, 1999.).

Integritet je jedna od najvažnijih vrlina u poslovanju općenito, a Zauder (1992.) tu vrlinu naziva neophodnom rukovoditeljskom vrlinom (Murphy, 1999.). Unutar područja marketinga, poduzeća traže zaposlenike s integritetom da rade na svim organizacijskim razinama. Počevši od svakodnevnih aktivnosti kao što su posjet zubaru, vožnja s tuđim automobilom, ostavljanje djece u vrtiću podrazumijeva povjerenje jedne strane drugoj.

Oprost je vrlina koja je izrazito bitna, a specifična je u svojoj primjeni - oprost kada je najviše potreban, najmanja je vjerojatnost da će se uistinu i dogoditi (Cameron i Raza, 2002.). S druge strane, organizacije koje pokazuju vrlinu oprosta imaju izrazito poticajnu i inspirirajuću kulturu i atmosferu (Frederickson, 2000.) koja onda vodi i do veće razine zadovoljstva.

\subsection{Odnos individualnih moralnih obilježja i etike vrlina organizacije}

Etika vrlina unutar organizacije može se promatrati kao element internog marketinga u kontekstu postizanja zadovoljstva organizacijom i poslom, ali i u dimenziji eksternog utjecaja i to pružanjem veće vrijednosti kroz etično poslovno djelovanje. 
Dugo vremena pojam etike u poslovanju smatran je 'oksimoronom', to jest, ideja o tome da etika i poslovanje ne idu zajedno potekla je od vjerovanja da poslovni ljudi, da bi uspjeli u poslovanju, izlaze iz normalnih granica pravičnosti (Morse, 1999.). Milton Friedmann i Alfred Carr u svojim se djelima bave pitanjima poslovanja, društva i etike te zastupaju ideju o razdvojenosti poslovne i osobne etike (Morse, 1999.). Spomenuti mislioci ističu da su pravila potrebna za poslovanje i upravljanje poslovnim procesima sasvim različita od onih koja ljudi razvijaju za potrebe osobne etike. Nešto novija teorija od Carrove je ona Carrollova gdje autor opisuje takozvanog 'amoralnog' menadžera, koji smatra da poslovna i menadžerska praksa ne moraju biti vezane s osobnom moralnošću te da je takvo razmišljanje danas općeprihvaćeno (Morse, 1999.).

Etika vrlina je pristup koji prije svega veliča vrline i moralni karakter (Hursthouse, 1999.) te za razliku od ostalih teorija morala etika vrlina nalazi moral u činjenicama o ljudskoj naravi te se koncentrira na navike i dugoročne ciljeve (Arjoon, 2000.). Primjena etike vrlina pruža korisnu perspektivu u stvaranju smisla u raznim pitanjima moralnog karaktera pojedinca i njegovih transformacijskih utjecaja na ponašanje organizacije (Wang et al., 2015.) pa onda i osobnog zadovoljstva organizacijom.

Ako je poduzeće moralno dobro i vodi se etikom vrlina, ono je okrenuto prema ostvarivanju zajedničkih koristi s okolinom i članovima te okoline (Koehn, 1998.). Međutim, postavlja se pitanje na koji način se poduzeće okreće u tome smjeru i kako do toga doći (Koehn, 1998.). Ključna stavka u tome procesu jesu menadžeri - dobar menadžment nastoji njegovati okolinu u kojoj ljudi žele raditi jedni s drugima (Koehn, 1998.). Također, dobar menadžer zna da je prisila nemoralna te da će ispoljavati kontraproduktivne učinke (Koehn, 1998.). MacIntyre (1999.) ističe nužnost posjedovanja vrlina integriteta i postojanosti, a one se stječu u obitelji, školi ili crkvi (Martin, 2012.). „Posjedovati vrlinu integriteta znači odbiti biti jedna vrsta osobe u socijalnom kontekstu, a druga u ostalim. To znači imati skup nepopustljivih granica koje ograničavaju popustljivost zbog uloge koju je potrebno preuzeti. Konzistentnost, kao i integritet, postavlja granice karakternoj fleksibilnosti“" (McPherson, 2013.). Kako bismo došli u fazu posjedovanja vrlina u cijelosti, moramo shvatiti da vrline ne možemo koristiti i iskazivati povremeno i po potrebi, čestite aktivnosti slijede iz čvrstog i dosljednog karaktera (McPherson, 2013.). Čestita osoba je motivirana za izvođenje čestitih aktivnosti osjećajem postignuća koji doživljava prilikom izvođenja takvih aktivnosti. Kupperman (1991.) se fokusira na karakter i vrline vidi kao ograničene: „Trebamo nešto više od skupa vrlina, trebamo dobar karakter. Dobar karakter sadrži prikladne interese i obvezivanje koji su različiti od sposobnosti, navika i kognitivnih vještina povezanih s moralom“ (Murphy, 1999.). Prikladne se vrline uočavaju prilikom prisustvovanja i svjedočenja čestitom ponašanju. Da bi osoba postala čestita mora vidjeti druge kako prakticiraju vrline i moralno ponašanje, a takvo se ponašanje najčešće uči od roditelja, starijih, učitelja i ostalih uzora s kojima se kroz život nalazimo u interakciji (Murphy, 1999.).

\subsection{Moralni karakter zaposlenika i zadovoljstvo organizacijom}

Zadovoljstvo poslom može se definirati kao osjećaj koji proizlazi iz percepcije ispunjenja obavljanjem određenog posla odnosno ispunjenjem osobnih vrijednosti uživanjem u poslovnim aktivnostima (Noe et al., 2006.). U takvom promatranju zadovoljstva poslom kao ključni ističu se elementi osobnog doživljaja, osobnih vrijednosti te individualne (osob- 
ne) perspektive. Iz čega proizlazi da su pojedinci zadovoljni s poslom sve dok je on u skladu s njihovim vrijednostima (Noe et al., 2006:321) u ovome slučaju moralnim karakterom zaposlenika. Zadovoljstvo zaposlenika je sastavni dio predanosti koja se temelji na kompatibilnosti s vrijednostima poduzeća, identifikacijom s poduzećem, lojalnosti te primjerice osjećaju da su pravedno nagrađeni za svoj rad (Blanken i Schrieber, 2005.). Kompatibilnost s vrijednostima odnosno karakterom izravno bi trebalo utjecati na zadovoljstvo organizacijom. Cameron i drugi (2004.) su došli do najznačajnijeg zaključka za suvremeno poslovanje i primjenu etike vrlina; dokazali su statistički značajnu povezanost između percipirane etike pet odabranih vrlina i organizacijskih rezultata. Takvi rezultati upućuju na činjenicu da etika pozitivno utječe na rezultate poslovanja suprotno uvriježenoj percepciji kako primjena iste dovodi do nepovoljnih ustupaka.

Singhapakdi i Vitell (1993.) su zaključili kako se rasuđivanja temelje i na osobnim i na profesionalnim etičkim vrijednostima. Prema Ferrellu i Greshamu (1985.) na menadžersko etičko odlučivanje utječu faktori poput onih individualnih, socijalnih, kulturoloških, značajnih osoba te prilika i situacijskih čimbenika. Individualni se čimbenici sastoje od vrijednosti, znanja, stavova i namjera osobe zadužene za odlučivanje, a u ovome su istraživanju od posebnoga značaja (Rallapalli et al., 2000.). Također, osobne vrijednosti su povezane s organizacijskim vrijednostima (Aakah i Lund, 1994.).

Prema Arjoonu (2000.) pojedinac čija motivacija koja nije isključivo vođena zaradom $\mathrm{u}$ dimenziji vlastitih moralnih vrlina očekuje nagradu u vidu unutarnjeg dobra odnosno zadovoljstva. Iz čega posljedično proizlazi hipoteza da oni pojedinci čija je percepcija organizacijskih vrlina visoka pokazuju veće zadovoljstvo organizacijom.

Kada pojedinci unutar organizacije primjećuju empatiju i iskuse zahvalnost ili oprost to dovodi do pozitivnih emocija poput ljubavi i entuzijazma koje su onda pravi pokazatelj uspjeha i organizacijskog uspjeha jer kao nuspojavu imaju bolje kongintivno funkcioniranje, bolje donošenje odluka te bolje međusobno funkcioniranje i stvaranje odnosa unutar organizacije (Murphy, 1999.).

\section{KVALITATIVNO ISTRAŽIVANJE MEĐUODNOSA OSOBNIH ČIMBENIKA I ETIČKIH ČIMBENIKA ORGANIZACIJA}

Kombinirana metoda istraživanja, gdje kvalitativno prethodi kvantitativno, korištena je s ciljem sveobuhvatnog i pragmatičnog utvrđivanja povezanosti fenomena. Naime, kvalitativno istraživanje provedeno je s ciljem istražiti povezanost osobnih moralnih čimbenika i profesionalnih moralnih čimbenika u kontekstu pet odabranih vrlina te otkriti na koji način se ostvaruje etički karakter organizacije. Korištenje kombinirane metode istraživanja preporučuje se u slučajevima kada istraživač želi elaborirati, dodatno ilustrirati i potvrditi povezanost fenomena koristeći pozitivne strane različitih metoda istraživanja s ciljem ostvarivanja metodološkog pluralizma (Johnson et. Al., 2007.; Johnson i Onwueguzie, 2004.)

Bitno je istražiti kod kojih vrlina organizacije, upravo organizacija ima dominantan utjecaj na pojedinca, ali ne iz pozicije prisile već potrebe usuglašavanja osobnih vrijednosti s onima organizacije. Upravo je takvo usuglašavanje potvrda potencijalne povezanosti etike vrlina sa zadovoljstvom organizacijom. Radi što kvalitetnijeg prodiranja u srž pro- 
blema koje odlikuje kvalitativnu metodu istraživanja (Tkalac Verčič et al., 2010.), a tako i pronalaska rješenja, provedeno je izviđajno kvalitativno istraživanje. $\mathrm{S}$ obzirom na to da je etika osjetljivo područje, instrument istraživanja bio je dubinski intervju koji je ispitanicima jamčio anonimnost. Istraživanje je provedeno tijekom 2015. godine. U uzorak je odabrano deset visokopozicioniranih stručnjaka iz različitih poduzeća te su s njima provedeni dubinski intervjui. Karakteristike ispitanika prikazane su u sljedećoj tablici.

Tablica I.: Karakteristike ispitanika

\begin{tabular}{|l|l|l|l|l|l|}
\hline Ispitanik & $\begin{array}{c}\text { Dobna } \\
\text { skupina }\end{array}$ & Spol & $\begin{array}{l}\text { Obrazovanje } \\
\text { i zanimanje }\end{array}$ & \multicolumn{1}{|c|}{ Pozicija } & \multicolumn{1}{|c|}{ Industrija } \\
\hline Osoba 1 & Rane 40-e & Ženski & VŠS & Brand menadžer & Pivarska industrija \\
\hline Osoba 2 & Srednje 30-e & Ženski & VSS & $\begin{array}{l}\text { Voditelj grupe } \\
\text { proizvoda }\end{array}$ & Pivarska industrija \\
\hline Osoba 3 & Kasne 30-e & Ženski & VŠS & $\begin{array}{l}\text { Direktor } \\
\text { marketinga }\end{array}$ & $\begin{array}{l}\text { Prehrambena } \\
\text { industrija }\end{array}$ \\
\hline Osoba 4 & Kasne 30-e & Ženski & VSS & $\begin{array}{l}\text { Menadžer za } \\
\text { odnose s javnošću }\end{array}$ & $\begin{array}{l}\text { Komunalno } \\
\text { poduzeće }\end{array}$ \\
\hline Osoba 5 & Rane 40-e & Muški & VSS & Direktor prodaje & IT industrija \\
\hline Osoba 6 & Rane 30-e & Ženski & VSS & $\begin{array}{l}\text { Asistent menadžer } \\
\text { kategorije } \\
\text { proizvoda }\end{array}$ & $\begin{array}{l}\text { Prehrambena } \\
\text { industrija }\end{array}$ \\
\hline Osoba 7 & Rane 30-e & Muški & VSS & $\begin{array}{l}\text { Trade marketing } \\
\text { direktor }\end{array}$ & $\begin{array}{l}\text { Prehrambena } \\
\text { industrija }\end{array}$ \\
\hline Osoba 8 & Srednje30-e & Ženski & VŠS & $\begin{array}{l}\text { Voditelj trade } \\
\text { marketinga i } \\
\text { kategorije }\end{array}$ & $\begin{array}{l}\text { Industrija } \\
\text { bezalkoholnih } \\
\text { pića }\end{array}$ \\
\hline Osoba 9 & Srednje 40-e & Ženski & VŠS & $\begin{array}{l}\text { Direktor } \\
\text { marketinga }\end{array}$ & $\begin{array}{l}\text { Automobilska } \\
\text { industrija }\end{array}$ \\
\hline Osoba 10 & Kasne 40-e & Muški & VSS & $\begin{array}{l}\text { Farmaceutska } \\
\text { Direktor prodaje }\end{array}$ \\
\hline
\end{tabular}

Izvor: izrada autorice.

\subsection{Rezultati kvalitativnog istraživanja}

S obzirom na dosadašnja iskustva, većina ispitanika ocijenila je da smatra da njihovi kolege i poslovni suradnici primjenjuju jednake obrasce ponašanja u privatnome životu, dakle kod kuće, u obitelji kao i na poslu. Jednako tako, smatraju da su takvi obrasci ponašanja neodvojivi, iako su neki ispitanici odgovorili kako su se susreli s većinom suradnika koji odvajaju privatne moralne obrasce ponašanja s onim poslovnima. Jedan ispitanik smatra da obrasci ponašanja ne smiju biti odvojeni: „Smatram kako moralno ponašanje u poslu ne može biti (i ne smije biti) odvojeno od moralnog ponašanja u privatnom životu pojedinca, već da štoviše ono proizlazi iz „privatnog“ morala i nadovezuje se na moralno ponašanje u privatnom životu. "Na pitanje smatraju li da njihovi kolege i suradnici poslovne odluke 
temelje na vlastitim moralnim načelima ili na pravilima poduzeća koja im ono nalaže, četiri su ispitanika odgovorila da misle da njihovi kolege svoje odluke temelje na vlastitim vrijednostima, dok je jednak broj ispitanika odgovorio da se u praksi ljudi vode i vrijednostima, ali i pravilima poduzeća. Jedan je ispitanik izrazio žaljenje što se više njegovih kolega ne vodi svojim unutrašnjim moralnim načelima: „Na žalost, bojim se da samo u teoriji postoje slučajevi gdje su zaposlenici u mogućnosti u potpunosti se osloniti na vlastite moralne porive, međutim, živimo u doba kada su korupcija i mito česta pojava, pa je tako i nepovjerenje između poduzeća i zaposlenika veliko, stoga se zaposlenici trebaju striktno držati pravila $i$ ne odstupati od njih. Svako bi odstupanje, iako bi ono i dalje bilo u moralnim okvirima, izazivalo negativne konotacije."

Primjer moralne odluke koju je jedan od ispitanika naveo je onaj kada je poduzeće povuklo proizvode $s$ tržišta zbog interne sumnje na nedopuštene spojeve u proizvodu (aflatoksine), međutim, njihova konkurencija to nije učinila. U tome je slučaju briga za potrošača bila veća od ostvarenja profita.

Dobrim karakterom ispitanici smatraju posjedovanje karakternih osobina poput otvorenosti suradnji, strasti, strukturiranosti, organiziranosti, kompetencije, posjedovanja empatije i integriteta. Osoba koja posjeduje dobar karakter stremi postizanju ciljeva poduzeća u dobroj vjeri, uzima u obzir potrošača i sve ostale sudionike procesa te gradi odnose na način da oni postaju dugoročni. Neovisno o kojoj se industriji radi, povjerenje i integritet su ključni. „Dobar karakter podrazumijeva maksimalnu korektnost prema poslovnim zadacima i razboritost kod donošenja poslovnih odluka. To znači da zaposlenik svaki zadatak treba odrađivati maksimalno angažirano, treba težiti izvrsnosti u egzekuciji i treba se voditi moralnim kompasom pravednosti pri donošenju poslovnih odluka.“

Ispitanici smatraju da je dobar karakter poželjan za rad u poduzeću, a prema nekima je, posebice u korporacijama, nužan. Dobar karakter osobu ne dovodi u sukobe sa zaposlenicima i manje su šanse da će osoba koja posjeduje dobar karakter oštetiti poduzeće na neki način. Što se tiče opravdanosti situacije da poduzeće traži od zaposlenika da odstupaju od vlastitih moralnih načela, jedan je ispitanik dao sljedeći odgovor: „Ukoliko je ono što poduzeće traži od zaposlenika da učini inferiornije u odnosu na njegove osobne koncepte pravde i morala, to je za svaku osudu. Opravdano bi jedino bilo tražiti da osoba odstupa od vlastitih pojmova pravičnosti ako ona odstupaju od određenog standarda i ne uklapaju se u etički sustav poduzeća, međutim takvi su slučajevi rijetkost. " Postoje i obratni slučajevi, naime države u kojima je mito i korupcija standard, a strana se poduzeća ne prilagođavaju takvim standardima. Zaposlenicima takvih poduzeća na neki je način teže poslovati, jer su, s obzirom na konkurenciju koja se koristi nedozvoljenim tehnikama, u nepovoljnijem položaju. S druge strane, poduzeća za koja rade očekuju da ostvare planove, koji su kreirani u normalnim poslovnim uvjetima. U takvim se slučajevima zaposlenici trebaju prilagođavati moralno iskrivljenim poslovnim sustavima.

Društveno je uvriježeno mišljenje kako su amoralni menadžeri, kod kojih je osobna etika nepovezana s poslovnom etikom i uspješniji. Međutim, ispitanici su jednoglasni u suprotnom te se ne slažu s tom tvrdnjom. Dakako, sve ovisi o kulturi koju poduzeće potiče, ali u pravilu su uspješniji oni zaposlenici koji u svojemu etičkom sustavu imaju integrirane osobne i profesionalne vrijednosti. Poštivanje samo etičkog kodeksa poduzeća nije dovoljno niti za prosperitet zaposlenika osobno, organizacijske jedinice ni poduzeća u cijelosti. Za uspjeh je, prema jednom ispitaniku, potrebna, čak i „kreativna sposobnost, da se izdigne iz 
mase drugih zaposlenika te svojim pravilnim i etičkim odlukama pridonese prosperitetu, kako vlastitom tako i organizacijskom. Kombinacija vlastitih moralnih vrijednosti i poštivanje pravila poduzeća, zakona države i društvenih normi ono je što osigurava uspjeh." Zaposlenici ne bi trebali vlastite moralne koncepcije ostavljati postrani radi ulaska u poslovni svijet ili određenu organizaciju, ako one ne odstupaju u negativnome smislu od onih standardiziranih u poduzeću. Kada bi zaposlenici morali mijenjati svoje stavove i moralna načela i koristiti one koje su im nametnute politikama poduzeća, postali bi nemotivirani, nezainteresirani i neefikasni u svojemu poslu.

Posve je razvidno kako u svim situacijama doprinos pružaju profesionalne organizacijske te osobne vrijednosti i moralna načela. Međutim, rezultati istraživanja su pokazali kako kod donošenja profesionalnih odluka karakter organizacije posebno kroz vrline povjerenja, integriteta i poštenja imaju snagu utjecati na vrijednosti pojedinca pri donošenju odluka. Vrline organizacije i te kako doprinose snazi organizacije na način da je onda donošenje osobnih, profesionalnih etičkih prosudbi jasnije. Osim toga, jasno je kako organizacijske vrline inspiriraju zaposlenike i pozitivno utječu na individualno donošenje odluka te na percipiranu svrhovitost posla i osobnu predanost poslu. Upravo su to preduvjeti zadovoljstva zaposlenika i motivacije što je jasna potvrda predviđenog cilja istraživanja, točnije, utvrđivanja indikacije povezanosti osobnih moralnih načela, etičkog karaktera poduzeća i zadovoljstvom organizacijom.

\section{KVANTITATIVNO ISTRAŽIVANJE ETIKE VRLINA U HRVATSKIM PODUZEĆIMA}

Nakon provedenoga izviđanog kvalitativnog istraživanja pristupilo se kvantitativnom istraživanju etike vrline u hrvatskim poduzećima. Potaknuti dobivenim rezultatima eksplorativnog kvalitativnog istraživanja, kvantitativno istraživanje imalo je cilj istražiti karakter hrvatskih organizacija te potvrditi utjecaj organizacijskih vrlina sa zadovoljstvom organizacijom visokopozicioniranih zaposlenika.

Instrument istraživanja, anketni upitnik bio je podijeljen u dva dijela, prvi dio se odnosio na 15 čestica skale etike vrlina preuzete od Cameron i drugih (2004.) te drugog u kojemu su se nalazila pitanja o zadovoljstvu organizacijom te općenitih informacija o poduzeću. Cameron i suradnici (2004.) razvili su skalu etike sljedećih 5 vrlina: optimizam, povjerenje, empatija, integritet i oprost u kojoj su dokazali sva potrebna statistička obilježja. Svaka od vrlina određena je trima tvrdnjama. Pitanja o etici vrlina testirana su na Likertovoj skali od 7 stupnjeva gdje su ispitanici bili upitani da iskažu vlastitu percepciju pojedinih elemenata etike vrlina. Anketni upitnik je preveden i predtestiran te je nakon osiguravanja jednoznačnosti i nedvosmislenosti proveden. Pitanje o percepciji zadovoljstva organizacijom također je testirano na Likertovoj skali od 7 stupnjeva.

Uzorak stručnjaka činili su menadžeri hrvatskih poduzeća. Lista poduzeća napravljena je po podacima FINA-e (Gospodarska Hrvatska). Istraživanje je provedeno putem online programskoga sučelja u vremenu od veljače do svibnja 2015. godine. Kao izvori kontakata koristili su se privatni izvori, poznanstva, javno dostupni podaci te profesionalna društvena mreža LinkedIN. Upitnik je bio postavljen na internetskom sučelju Qualtrics te je bio poslan na otprilike 2000 adresa od čega je nakon slanja jednog podsjetnika prikupljeno 
168 u potpunosti popunjenih upitnika, što predstavlja procijenjenu stopu povrata od 8,4 \%. Dobiveni rezultati su obrađeni u statističkome programu SPSS.

Uzorak označava velika raznolikost prema industrijama, najzastupljenija su poduzeća koja se bave proizvodnjom njih čak $39 \%$, slijede poduzeća koja se bave isporukom različitih usluga $16 \%$, kao i poduzeća iz sektora informacijske tehnologije $13 \%$, građevine $5 \%$ i energetike $5 \%$. Također su zastupljena poduzeća iz sektora marketinga i odnosa s javnošću, turizma, farmaceutske industrije, poljoprivrede, ugostiteljstva, turizma i brodogradnje. Poduzeća su gotovo podjednako zastupljena s obzirom na dominantnu proizvodnu odnosno uslužnu orijentaciju; njih $52 \%$ na tržištu nastupa dominantno s proizvodima, a ostali s uslugama.

\subsection{Rezultati kvantitativnog istraživanja}

Analiza rezultata provedenoga istraživanja započeta je provedbom eksplorativne faktorske analize pet vrlina: optimizam, povjerenje, empatija, integritet i oprost. Za provedbu takve analize Hair i suradnici (2010:102) sugeriraju da bi veličina uzorka trebala biti minimalno 100 što je ispunjeno. Korištena je metoda glavnih komponenti bez rotacije, a adekvatnost promatranoga uzorka za izvođenje eksplorativne faktorske analize testirana je Kaiser-Meyer-Olkin (KMO) testom koji pokazuje prikladnost podataka za faktorsku analizu na temelju korelacijske matrice te Barlett-ovim testom sferičnosti (Hair et al. 2010:92). Za sve faktore je zadovoljeno da je vrijednost KMO-a veća od 0,6, a Bartlettov test statistički značajan $(\mathrm{p}<0,05)$.

Tablica III. pokazuje rezultate faktorske analize na 5 odabranih vrlina te razinu pouzdanosti mjerenja svake varijable odabranim česticama. Pouzdanost se utvrđivala standardnom metodom izračunavanja pouzdanosti skale pomoću Chronbach alpha koeficijenta čija vrijednost mora biti iznad 0,6 te indikatorom item-to-total korelacije koji bi trebala biti iznad 0,5 te su sve inter-item korelacije unutar faktora veće od 0,3 (Hair et al, 2011:125). Pripadajući Crhonbach alpha koeficijenti te srednje vrijednosti su prikazane u tablici koja slijedi, a inter-item korelacije sve prelaze 0,3 i jamče homogenost faktora, ali nisu prikazane u radu.

Rezultati upućuju na relativno visoku razinu percepcije virtuoznosti odnosno karaktera organizacije kod svih pet vrlina gdje sve srednje vrijednosti faktora iznose više od 5,5. Stoga je iz rezultata moguće iščitati kako hrvatske organizacije imaju visoku razinu poželjnih vrlina, ako je suditi prema percepciji visokopozicioniranih ispitanika. Od testiranih pet vrlina posebno se ističe povjerenje koje ima najvišu srednju vrijednost 5,954, te ju slijede integritet $\mathrm{i}$ oprost. 
Tablica II: Faktorska analiza i pouzdanost 5 organizacijskih vrlina

\begin{tabular}{|c|c|c|c|c|}
\hline Varijabla i čestice & $\begin{array}{c}\text { Faktorsko } \\
\text { opterećenje }\end{array}$ & $\begin{array}{c}\text { Cronbach } \\
\text { Alpha }\end{array}$ & $\begin{array}{c}\text { Srednja } \\
\text { vrijednost }\end{array}$ & $\begin{array}{c}\text { Standardna } \\
\text { devijacija }\end{array}$ \\
\hline \multicolumn{5}{|l|}{ Optimizam } \\
\hline $\begin{array}{l}\text { Osjećaj više svrhe povezan s onim što } \\
\text { radimo u poduzeću }\end{array}$ & 0,842 & \multirow{3}{*}{0,840} & \multirow{3}{*}{5,647} & \multirow{3}{*}{1,235} \\
\hline $\begin{array}{l}\text { U ovome poduzeću posvećeni smo tome da } \\
\text { činimo dobro uz to da radimo dobro. }\end{array}$ & 0,915 & & & \\
\hline $\begin{array}{l}\text { Optimistični smo da ćemo uspjeti čak } \\
\text { i onda kada se susrećemo s velikim } \\
\text { izazovima. }\end{array}$ & 0,854 & & & \\
\hline \multicolumn{5}{|l|}{ Povjerenje } \\
\hline $\begin{array}{l}\text { U ovome poduzeću zaposlenici vjeruju } \\
\text { jedni drugima. }\end{array}$ & 0,904 & \multirow{3}{*}{0,893} & \multirow{3}{*}{5,954} & \multirow{3}{*}{1,105} \\
\hline $\begin{array}{l}\text { U ovome poduzeću ljude se tretira s } \\
\text { pristojnošću, uvažavanjem i poštovanjem. }\end{array}$ & 0,922 & & & \\
\hline Ljudi vjeruju vodstvu ovoga poduzeća. & 0,897 & & & \\
\hline \multicolumn{5}{|l|}{ Empatija } \\
\hline $\begin{array}{l}\text { Djela milosrđa su česta u ovome } \\
\text { poduzeću. }\end{array}$ & 0,904 & \multirow{3}{*}{0,914} & \multirow{3}{*}{5,504} & \multirow{3}{*}{1,303} \\
\hline $\begin{array}{l}\text { Ovo poduzeće karakterizira skrb i briga za } \\
\text { druge ljude. }\end{array}$ & 0,932 & & & \\
\hline $\begin{array}{l}\text { Mnoge priče o suosjećanju i brizi kruže } \\
\text { među djelatnicima ovoga poduzeća. }\end{array}$ & 0,932 & & & \\
\hline \multicolumn{5}{|l|}{ Integritet } \\
\hline $\begin{array}{l}\text { Iskrenost i povjerenje su simboli ove } \\
\text { organizacije. }\end{array}$ & 0,910 & \multirow{3}{*}{0,874} & \multirow{3}{*}{5,798} & \multirow{3}{*}{1,117} \\
\hline $\begin{array}{l}\text { Ovo poduzeće pokazuje najvišu razinu } \\
\text { integriteta. }\end{array}$ & 0,907 & & & \\
\hline $\begin{array}{l}\text { Ovo poduzeće moglo bi biti opisano kao } \\
\text { časno i čestito. }\end{array}$ & 0,871 & & & \\
\hline \multicolumn{5}{|l|}{ Oprost } \\
\hline $\begin{array}{l}\text { Trudimo se učiti iz vlastitih pogrešaka, } \\
\text { zbog čega greške brzo opraštamo. }\end{array}$ & 0,893 & \multirow{3}{*}{0,876} & \multirow{3}{*}{5,788} & \multirow{3}{*}{1,178} \\
\hline Ovo poduzeće oprašta te je suosjećajno. & 0,904 & & & \\
\hline $\begin{array}{l}\text { Imamo vrlo visoke standarde djelovanja, } \\
\text { ali opraštamo greške kada su priznate i } \\
\text { ispravljene. }\end{array}$ & 0,892 & & & \\
\hline \multicolumn{5}{|l|}{$n=168$} \\
\hline
\end{tabular}

Nakon analize faktora svake od vrlina organizacije provedena je empirijska analiza odrednica etike vrlina s ciljem utvrđivanja onih vrlina koje značajno utječu na zadovoljstvo organizacijom. S obzirom da je u upitniku testirano 5 određenih vrlina napravljena je ana- 
liza modela višestruke linearne regresije. Cilj analize je bio istražiti koja od vrlina utječe na zadovoljstvo organizacijom uz razinu značajnosti od $5 \%$.

Primjenom metode najmanjih kvadrata formiran je model višestruke linearne regresije u kojoj je zavisna varijabla zadovoljstvo organizacijom, dok su nezavisne varijable optimizam, povjerenje, empatija, integritet i oprost. Uvidom u pregled regresijskog modela vidljivo je kako je vrijednost koeficijenta višestruke linearne regresije 0,36 dok je modelom objašnjeno ukupno $34 \%$ varijance. Durbin-Watson se nalazi između dvije kritične vrijednosti $1.5<\mathrm{d}<2.5$ zbog čega zaključujemo kako ne postoji linearna autokorelacija.

Tablica III: Model višestruke linearne regresije

\begin{tabular}{|l|c|l|l|l|l|}
\hline \multicolumn{6}{|c|}{ Model Summary $^{\mathbf{b}}$} \\
\hline Model & $\mathrm{R}$ & R Square & $\begin{array}{c}\text { Adjusted R } \\
\text { Square }\end{array}$ & $\begin{array}{c}\text { Std. Error of } \\
\text { the Estimate }\end{array}$ & Durbin-Watson \\
\hline 1 &, $600^{\mathrm{a}}$ &, 360 &, 340 &, 858 & 2,222 \\
\hline
\end{tabular}

a. Predictors: (Constant), Forgiveness , Optimism, Compassion, Trust, Integrity

b. Dependent Variable: FIRMSATIS

Uvidom u rezultat F-testa dostupnog u tablici IV. vidljivo je kako je on statistički značajan, zbog čega možemo zaključiti kako postoji linearna veza varijabli odabranih u model.

Tablica IV: Značajnost modela višestruke linearne regresije

\begin{tabular}{|c|c|c|c|c|c|c|}
\hline \multicolumn{7}{|c|}{ ANOVA $^{a}$} \\
\hline \multicolumn{2}{|r|}{ Model } & $\begin{array}{c}\text { Sum of } \\
\text { Squares }\end{array}$ & df & $\begin{array}{l}\text { Mean } \\
\text { Square }\end{array}$ & $\mathrm{F}$ & Sig. \\
\hline \multirow{3}{*}{1} & Regression & 67,072 & 5 & 13,414 & 18,229 &, $000^{\mathrm{b}}$ \\
\hline & Residual & 119,214 & 162 & ,736 & & \\
\hline & Total & 186,286 & 167 & & & \\
\hline
\end{tabular}

a. Dependent Variable: FIRMSATIS

b. Predictors: (Constant), Forgiveness, Optimism, Compassion, Trust, Integrity

U tablici V. dan je regresijski model gdje odmah u koeficijentima možemo uočiti kako jedino oprost ima izrazito blagu negativnu povezanost sa zadovoljstvom organizacije, dok sve ostale vrline imaju pozitivnu povezanost. Indikativno je kako učenje iz vlastitih pogrešaka te opraštanje priznatih pogrešaka negativno utječe na zadovoljstvo organizacijom. Bitno je naglasiti da isti koeficijent je izrazito malen (vrlo blizak nuli) te nije statistički značajan.

Isto tako se ističe izrazito visok regresijski koeficijent povjerenja $\beta=0,289$ što sugerira da ta vrlina najviše utječe na zadovoljstvo organizacijom. Značajno se ističe i vrlina integriteta s koeficijentom $\beta=0,227$, nakon čega po veličini koeficijenta slijede empatija te optimizam. Nadalje, od svih vrlina upravo povjerenje statistički značajno utječe na zadovoljstvo organizacijom. Takav rezultat jasno ukazuje na povjerenje kao ključan element organizacijskog karaktera u stvaranju kvalitetnih odnosa unutar i izvan organizacije. 
Tablica V: Model višestruke linearne regresije utjecaja vrlina na zadovoljstvo organizacijom

\begin{tabular}{|c|l|r|r|r|r|r|}
\hline \multirow{2}{*}{$\begin{array}{c}\text { Model } \\
\text { B }\end{array}$} & \multicolumn{2}{c|}{$\begin{array}{c}\text { Unstandardized } \\
\text { Coefficients }\end{array}$} & $\begin{array}{c}\text { Standardized } \\
\text { Coefficients }\end{array}$ & \multirow{2}{*}{ t } & \multirow{2}{*}{ Sig. } \\
\cline { 3 - 7 } \multicolumn{2}{|c|}{} & Std. Error & Beta & & & \\
\hline \multirow{4}{*}{1} & (Constant) &, 094 &, 088 &, 089 & 1,070 &, 286 \\
\cline { 2 - 7 } & Optimizam &, 289 &, 144 &, 274 & 2,001 &, 047 \\
\cline { 2 - 7 } & Povjerenje &, 110 &, 117 &, 104 &, 937 &, 350 \\
\cline { 2 - 7 } & Empatija &, 227 &, 154 &, 215 & 1,474 &, 142 \\
\cline { 2 - 7 } & Integritet &,- 030 &, 110 &,- 028 &,- 272 &, 786 \\
\cline { 2 - 7 } & Oprost & & & & 87,419 &, 000 \\
\hline
\end{tabular}

\section{ZAKLJUČAK}

Strateški pristup društveno odgovornom poslovanju zapravo briše granice društvene odgovornosti i svakodnevnog funkcioniranja poduzeća što onda predstavlja suštinsko opredjeljenje poduzeća da postane odgovoran dionik tržišne utakmice. Etika vrlina nailazi na značajniju upotrebu u etičkoj praksi općenito, ali i u poslovnoj etici, pa tako umjesto pitanja 'Kakva osoba moram biti?’ postavljamo pitanje ‘Kakva poslovna osoba želim biti?' (Audi, 2012.).

Kako etika vrlina nalaže, vrline se moraju redovito vježbati i prakticirati te nisu odvojive samo za određene situacije, već moraju biti integrirane u ljudskom karakteru i korištene u svakoj situaciji. Tako je i s upotrebom moralnih načela na poslu. Osoba mora kontinuirano, dakle i izvan posla, prakticirati određene moralne aktivnosti, što znači da je nemoguće odvojiti osobnu etiku od one profesionalne. Iz rezultata ispitivanja može se ustvrditi da je u današnjoj praksi prisutna integracija osobnih i profesionalnih moralnih čimbenika i vrijednosti. Povjerenje kao karakterna vrlina ključan je preduvjet bilo kakvog poslovnog odnosa i to je potvrđeno $u$ oba provedena istraživanja što je u potpunosti u skladu s objavljenim teoretskim razmatranjima etike vrlina (Hosmer, 1994., MacIntyre, 1999., Murphy et. al, 2007.). Osim toga, posebno u kvalitativnom istraživanju potvrđena je važnost organizacijske vrline integriteta i postojanosti odnosno poticanja konzistentnosti vlastitog karaktera kada se radi o prilagodbi osobnih i profesionalnih moralnih načela u etičkom donošenju odluka predviđeno prethodno objavljenim radovima (MacIntyre, 1999.; Martin, 2012.; McPherson, 2013.). Iz provedenih istraživanja moguće je zaključiti kako hrvatska poduzeća imaju relativno jak etički karakter čije rukovodstvo prepoznaje da je poduzeće dio društvene zajednice te da mora raditi u skladu s ciljevima te zajednice. Etika vrlina pozitivno utječe na zadovoljstvo organizacijom te je izrazito učinkovit alat jer stvara one organizacijske i međuljudske vrijednosti čija snaga je u stanju prevladati situacijske okolnosti.

Glavno ograničenje ove vrste istraživanja jest pristranost odnosno vjerojatnost da ispitanici na neka pitanja odgovaraju neiskreno, s obzirom da je tematika istraživanja etika i etički koncepti. Taj se problem unaprijed pokušao prevladati, stoga su pitanja koja su bila postavljena ispitanicima bila projicirana na njihove kolege i suradnike odnosno organizaciju, a ne na sebe samog. Također, menadžeri koji su bili izvor informacija o percipiranim vrlinama također su odgovarali na pitanje osobnog zadovoljstva organizacijom. Iako je to metodološki čest slučaj, stvara ograničenje u vidu samo jednog izvora informacija za sve 
varijable u modelu odnosno dovodi do smanjene objektivnosti rezultata. Ovaj rad istražuje tematiku u situacijskom kontekstu te se ne temelji na dugoročnom promatranju te se zbog toga mora promatrati kontekstualno.

\section{LITERATURA:}

1. Annas, J. (2015) Applying Virtue to Ethics (Society of Applied Philosophy Annual Lecture 2014). Journal of Applied Philosophy, 32 (1), pp. 1-14.

2. Anca, P. (2010). Virtue Ethics-New Coordinates For Economic Development.Annals of Faculty of Economics, 1(2), 306-312.

3. Aranzadi, J. (2013). The natural link between virtue ethics and political virtue: the morality of the market. Journal of business ethics, 118(3), 487-496.

4. Arjoon, S. (2000) Virtue theory as a dynamic theory of business. Journal of Business Ethics, 28(2), 159-178.

5. Audi, R. (2012). Virtue ethics as a resource in business. Business Ethics Quarterly, 22(02), 273-291.

6. Bertland, A. (2009). Virtue ethics in business and the capabilities approach. Journal of Business Ethics, 84(1), 25-32.

7. Berčić, B. (2008): „Etika vrlina“, Philosophical Research, 28 (01), 193-207.

8. Blanken, H. i Schreiber, M. (2005). Vertriebssteuerung durch Human Resource Management: Aussendienstmotivation und Vertriebseffektivität als Schlüssel zum Markterfolg.St.Galler Trendmonitor für Risiko- und Finanzmärkte, 1. 11.

9. Bruni, L., \& Sugden, R. (2013). Reclaiming virtue ethics for economics. The Journal of Economic Perspectives, 27(4), 141-163.

10. Cameron, K. S. (2003). Organizational virtuousness and performance.In KS Cameron, J. Dutton \& RE Quinn (Eds.), Positive Organizational Scholarship (pp. 48-65).

11. Cameron, K. S., Bright, D., \& Caza, A. (2004). Exploring the relationships between organizational virtuousness and performance. American Behavioral Scientist, 47(6), 766-790.

12. Cameron, K., \& Caza, A. (2002). Organizational and leadership virtues and the role of forgiveness. Journal of Leadership \& Organizational Studies, 9(1), 33-48.

13. Collier, J. (1995). The virtuous organization. Business Ethics: A European Review, 4(3), 143-149.

14. Dobson, J. (2007). Applying Virtue Ethics to Business: The Agent-Based Approach. Journal of Business Ethics and Organization Studies, 12 (2). pp. 1-4.

15. Ferrell, O. C., \& Gresham, L. G. (1985). A contingency framework for understanding ethical decision making in marketing. The Journal of Marketing, 87-96.

16. Friedman, M. (1970). The social responsibility of business is to increase its profits (pp. 173-178). Springer Berlin Heidelberg.

17. Fredrickson, B. L. (2000). Why positive emotions matter in organizations: Lessons from the broaden-and-build model. The Psychologist-Manager Journal, 4(2), 131. 
18. Garcia-Ruiz, P., \& Rodriguez-Lluesma, C. (2014). Consumption practices: A virtue ethics approach. Business Ethics Quarterly, 24(04), 509-531.

19. Hair, J. F. i Tatham, R. L. i Anderson, R. E. i Black, W. (2010) Multivariate data analysis. 7. izd. Upper Saddle River, NJ: Pearson Prentice Hall.

20. Hosmer, L. T. (1994). Why be moral? A different rationale for managers. Business Ethics Quarterly, 4(02), 191-204.

21. Hursthouse, R. (1999) On virtue ethics. Oxford: Oxford University Press.

22. Johnson, R. B., Onwuegbuzie, A. J., \& Turner, L. A. (2007). Toward a definition of mixed methods research. Journal of mixed methods research, 1(2), 112-133.

23. Johnson, R. B., \& Onwuegbuzie, A. J. (2004). Mixed methods research: A research paradigm whose time has come. Educational researcher, 33(7), 14-26.

24. Koehn, D. (1998). Virtue ethics, the firm, and moral psychology. Business Ethics Quarterly, 8(03), 497-513.

25. MacIntyre, A. (1999). Social structures and their threats to moral agency.Philosophy, 74(03), 311-329.

26. Mintz, S. M. (1996). Aristotelian virtue and business ethics education. Journal of Business Ethics, 15(8), 827-838.

27. McPherson, D. (2013). Vocational virtue ethics: Prospects for a virtue ethic approach to business. Journal of business ethics, 116(2), 283-296.

28. Moore, G. (2008). Re-imagining the morality of management: A modern virtue ethics approach. Business Ethics Quarterly, 18(04), 483-511.

29. Morse, J. (1999). The missing link between virtue theory and business ethics.Journal of Applied Philosophy, 16(1), 47-58.

30. Murphy, P. E., Laczniak, G. R., \& Wood, G. (2007). An ethical basis for relationship marketing: a virtue ethics perspective. European Journal of Marketing, 41(1/2), 3757.

31. Murphy, P. E. (1999). Character and virtue ethics in international marketing: An agenda for managers, researchers and educators. Journal of Business Ethics,18(1), 107124.

32. Noe, R. A., Hollenbeck, J. R., Gerhart, B., \& Wright, P. M. (2006). Menadžment ljudskih potencijala.

33. Rallapalli, K. C., Vitell Jr, S. J., \& Szeinbach, S. (2000). Marketers' norms and personal values: an empirical study of marketing professionals. Journal of Business Ethi$c s, 24(1), 65-75$.

34. Singhapakdi, A., \& Vitell, S. J. (1993). Personal and professional values underlying the ethical judgments of marketers. Journal of Business Ethics,12(7), 525-533.

35. Tkalac Verčić, A., Sinčić Ćorić, D., \& Pološki Vokić, N. (2010.). Priručnik za metodologiju istraživačkog rada. Zagreb: MEP.

36. Wang, Y., Cheney, G., Roper, J. (2014) Virtue Ethics and the Practice- Institution Schema: An Ethical Case of Excellent Business Practices. Journal of Business Ethics, 138 (1), str. 67-77. 